This item was submitted to Loughborough's Research Repository by the author.

Items in Figshare are protected by copyright, with all rights reserved, unless otherwise indicated.

\title{
Elite athletes and university education in Europe: a review of policy and practice in higher education in the European Union Member States
}

\section{PLEASE CITE THE PUBLISHED VERSION}

http://dx.doi.org/10.1080/19406941003634024

\section{PUBLISHER}

Routledge (@ Taylor \& Francis)

VERSION

AM (Accepted Manuscript)

\section{LICENCE}

CC BY-NC-ND 4.0

\section{REPOSITORY RECORD}

Aquilina, Dawn A., and lan P.D. Henry. 2019. "Elite Athletes and University Education in Europe: A Review of Policy and Practice in Higher Education in the European Union Member States". figshare. https://hdl.handle.net/2134/15226. 
This item was submitted to Loughborough's Institutional Repository (https://dspace.lboro.ac.uk/) by the author and is made available under the following Creative Commons Licence conditions.

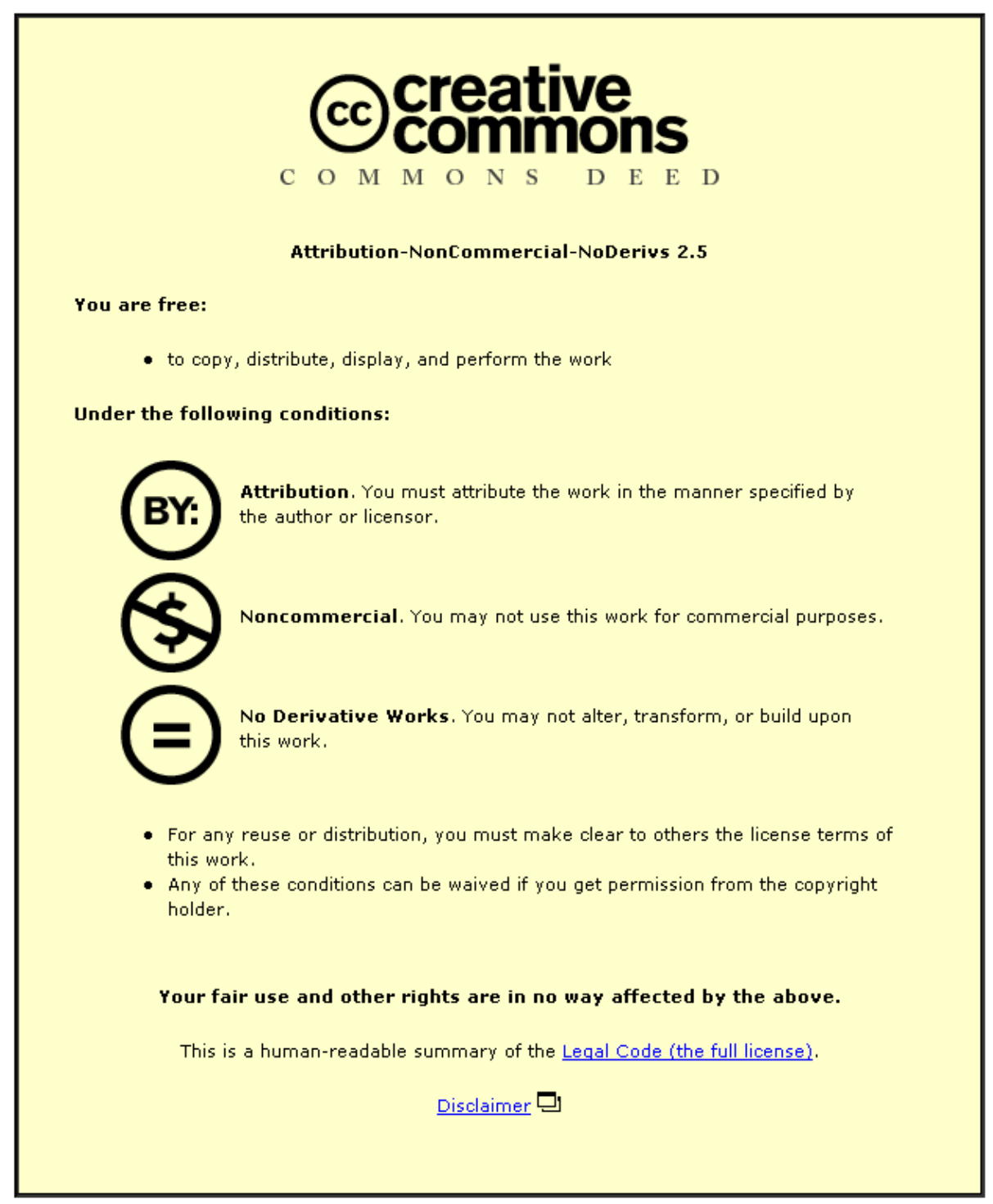

For the full text of this licence, please go to: http://creativecommons.org/licenses/by-nc-nd/2.5/ 
Elite athletes and university education in Europe: a review of policy and practice in higher education in the European Union Member States,

International Journal of Sport Policy and Politics, 2:1, 25-47

Dawn Aquilina* and lan Henry

Centre for Olympic Studies and Research, Loughborough University, Loughborough, UK

\begin{abstract}
This article provides an analysis of the ways in which European Union Member States have sought to address the educational needs of elite young sportspersons. Drawing on fieldwork by 25 research teams led by the authors and undertaken on behalf of the European Commission, it reflects the European Union's increasing concern with protection of the rights of young athletes. Our focus in this paper is on higher education and its adaptation to accommodate the delivery of education to elite athletes. The review of policy descriptions undertaken highlighted three principal categories of policy initiative within the university sector namely the development of academic services, elite sporting provision, and postathletic career preparation. The findings of the study underlined the variability of response in national systems to the demands placed on elite young sportspersons. This has been more broadly linked to the relationship between general welfare ideologies in nation states, and the positions adopted in relation to education of their young athletes. We characterise these positions in a four-fold typology: (i) a state-centric provision backed by legislation, (ii) the state as a facilitator fostering formal agreements between educational and sporting bodies, (iii) National Federations / Sports Institutes as facilitator / mediator engaging directly in negotiation with educational bodies on behalf of the individual athlete, and (iv) a 'laisser faire' approach where there are no formal structures in place. Crucial to an evaluation of the systems summarised in the typology is an understanding of what these policy systems are seeking to achieve. This may be expressed in terms of a balance between the roles, rights and responsibilities of the main stakeholders including the athlete, the university, the Member State and the European Union.
\end{abstract}

Keywords: elite sport; academic and sporting services; educational rights; government Intervention 


\section{Introduction}

This paper reports an analysis of the ways in which European Union Members States have sought to address the educational needs of elite young sportspersons. The paper draws on fieldwork by 25 research teams led by the authors 1 and undertaken on behalf of the European Commission (Amara et al. 2004), which reflects the European Union's increasing concern with protection of the rights of young athletes. This policy concern has developed in the context of on-going proposals for policy change in relation to sport at EU level which are reflected for example in the proposals of the Lisbon Treaty to provide a 'soft' competence in sport, and in the publication of the European Commission's White Paper on Sport (European Commission 2007c).

This paper has four aims. First it seeks to identify, illustrate and explain approaches adopted by nation states to meet the higher education needs of elite young sportspersons; second it will illustrate ways in which such approaches imply roles and responsibilities not only for the state in providing educational opportunities to allow student-athletes to meet the demands of their joint role, but also for other stakeholders including the athletes themselves; third the paper will highlight the relationship between general welfare ideologies in nation states, and the positions adopted in relation to education of young sportspersons. Finally, given the variance in relation to both general welfare and to policy in this particular area, the paper will go on to consider the implications for the role of the European Union in respect of the education of young elite athletes.

\section{The literature on education and elite athletes in Europe}

The role of the EU in sport has grown considerably in importance in the last two decades. Although sport per se is still not an area in which the EU has a direct competence to act, nevertheless in so far as sport is a professional trading activity, or impinges on aspects of regional development, or social policy (such as combating social exclusion), the EU does have powers to act (Henry and Matthews 2001). Competition policy, regional development, or social cohesion policies may not be sports policies as such but they do impinge significantly on the level and visibility of action of the EU and the Commission on citizens' everyday experience of sport (Henry 2007).

There has been debate for some considerable time about whether the EU should have a competence, a legal basis for intervention in the field of sport (Parrish 2003). Concrete proposals were first debated in the discussions surrounding the passage of the Maastricht Treaty. Although there was some resistance within both the sporting and political worlds, a deal was brokered which appended a statement on sport to the Maastricht treaty following protracted negotiations (Henry and Matthews 1998). The statement, though fairly anodyne, signalled a will on the part of the majority to consider sport as a policy area for further action. A report to the Council of Ministers in Helsinki in 1999 resulted in the adoption of a Declaration on Sport as an appendix to the Nice Treaty on European Union. Though this declaration did not extend the powers of the EU it did signal the growing determination of the EU to act in the sports field in respect of the concerns of both amateur and professional sport, and more specifically in relation to the education and vocational needs of elite athletes. The Council of Ministers explicitly recognised the importance of addressing such issues in Annex IV to the Presidency Conclusions to the Nice European Council Meeting (7-9 December 2000) which urged:

the need for special heed to be paid, in particular by sporting organisations, to the education and vocational training of top young sportsmen and -women, in order that their vocational integration is not jeopardised because of their sporting careers. (European Council of Ministers 2000)

In the early part of the 21st century the EU was absorbed in the consequences of rapid expansion and the perceived need for a more formalised framework to accommodate the increasingly complex policy context of a European Union which had grown from15 to 25 and then 27 Member States. The inclusion of an article in the EU Treaty establishing a Constitution for Europe signed by the Council of Ministers in 2004 (but dropped following rejection in referenda in France and the Netherlands in 2005) represented a further step in the process of formalising the EU's role in sport policy as a 
competence. In the Lisbon Reform Treaty, drawn up to replace the failed Constitution, an element of Article 165 provides authority for a 'soft' competence declaring that in respect of sport the 'Union shall have competence to carry out actions to support, coordinate or supplement the actions of the Member States' and that the EU would 'develop the European dimension in sport, by promoting fairness and openness in sporting competitions and cooperation between bodies responsible for sports, and by protecting the physical and moral integrity of sportsmen and sportswomen, especially the youngest sportsmen and sportswomen' (European Commission 2007b, p. 110). While at the time of writing this Treaty was due to be ratified by June 2009, its passage in some Member States still appeared to be potentially problematic, and indeed it may have been dealt a fatal blow by the failure of the Irish referendum of June 2008 to secure a yes vote. Nevertheless its inclusion of sport as a competence reflects a continuing determination to address certain sporting issues.

The European Commission's White Paper on Sport (European Commission 2007c) incorporated a series of policy actions, (summarised within the 'Coubertin Plan', European Commission 2007). While the White Paper was clearly intended to pave the way for work on a programme following acceptance of a competence in the Lisbon Treaty, nevertheless in most respects its proposed lines of action relied on existing competences covering other areas of policy. One of these areas is the protection of the interests of young athletes in respect of (among other matters) their educational rights and interests.

The issue of the rights of young elite sportsmen and women is one which reflects two sets of concerns. The first is the need to protect them from commercial and other pressures which may erode their access to vocational or educational development, thus placing them in potentially difficult situations following retirement from sport. The second, perhaps less obvious issue, is that of unfair competition between nation states when some nations permit the exploitation of young talent without reference to the educational requirements of the individual while others do not. In the same way as the introduction of a 'Social Chapter' in the Maastricht Treaty was designed to reduce unfair competition for jobs between Member States on the basis of different levels of workers' rights, an effect of the legislation here may be to minimise the impact on nation states of differential rights accorded to athletes in terms of access to education and training.

As Donnelly and Petherick (2004) argue there are currently few protections afforded to elite athletes by the state in the form of: limits on training time; limits on competitions; enforcement of the time that athletes devote to compulsory education; security and investing their income; and access to health and safety regulations. They further emphasise that both governments and sport organisations should ensure the education and healthy development of children and adolescents in the sport development systems' (Donnelly and Petherick 2004, p. 319) since statistics clearly illustrate that only a small percentage of these young people go on to become Olympic or professional athletes, and even where they do, post-athletic careers should be considered. Similarly, David (2005), in his book Human Rights in Youth Sport argues that the right to education of these sportspersons should not be neglected:

Too often the best interests of the child are not taken into consideration when a decision has to be made as to whether a child opts for intensive sport training or continues studying. Adults - parents, coaches, sponsors - tend to impose their choice on the young athlete. (David 2005, p. 185)

Commenting on David's work, Brackenridge argues that current elite sporting systems have tended to 'de-humanise' the athletes in their pursuit of success and they 'effectively exclude any concern for individual moral reasoning or political autonomy in the developing athlete as a performance machine' (Brackenridge 2004, p. 324).

The literature reflects therefore a need to foster ethical and sustainable practices by developing an elite sporting system which will be effective in the identification and nurturing of sporting talent, while still respecting the educational / vocational needs of young athletes. Adopting a rights perspective in sport as Brackenridge suggests could go some way to changing the current 'survivalist' methods to training that are characteristic of some sports and 'could lead to the empowerment of the individual athletes, better representation, reduction in their hours of training, increases in financial rewards and insurance protection, and better provision for long-term educational and career planning' (Brackenridge 2004, p. 334). However, perhaps the greatest challenge to such an approach, as Andrews (Andrews 1999) highlights, is that although sport forms part of the wider society and its legal system, it has often managed to operate in a legal lacuna. He explains: 
This is possible simply because local, national, regional and international sport federations have their own rules, administrative bodies and courts. There is nothing wrong with this, on the condition that those rules are defined and implemented in accordance with domestic and international law. But this is not always the case. (Andrews 1999, p. 61)

Giulianotti (2004) also points out that although there is a universal right to education as Article 26 in the Human Rights declaration stipulates, nevertheless there is evidence that among young elite athletes some have had to seriously compromise their educational development in favour of a potential elite sporting career. The reality for the majority of elite athletes is that even though they may be very successful on the world sporting stage they will never make a living out of their sport and will have to think of some alternative means to support themselves during and after their sporting career (David 1999). Within the context of this developing concern for the education of elite young sportsmen and women, this paper seeks to outline the nature of policy practice relating to higher education in the Member States of the EU.

As De Knop et al. point out 'It is only. . . [since the early 1990s]. . .that initiatives have been developed in Europe favouring the combination of academic and high level athletic activities' (De Knop et al. 1999, p. 51). The main driving force behind these initiatives was the acknowledgement by various entities of the rising pressures with which student-athletes have to cope in order to balance their academic and sporting commitments. Being an elite athlete has become increasingly demanding at a time when training volume and frequency of competition have clearly intensified (Conzelmann and Nagel 2003, p. 262). This has immediate implications for the lifestyle of the athlete in terms of time management, required effort and commitment to fulfil his or her role both as a student and athlete.

Since the beginning of the decade, the European Commission has also shown a growing concern with the multifaceted life of young sportspeople and has concentrated its efforts in particular on the protection of their access to educational opportunities (European Parliament 2003). The year 2004 was designated as the European Year of Education through Sport by the European Union Commission, and as part of this initiative it commissioned a number of studies and projects on a local, regional, national, transnational and community wide level, which aimed at investigating or promoting the links between sport and education in the 25 Member States of the EU. The budget for these projects was fairly substantial -approximately €12.1 million (European Commission 2004).

In addition to the European study on which this paper draws, a number of other major European studies concerning aspects of the education of elite sportspersons have also been recently commissioned notably, Education in Elite Sport in Europe (German Sport Confederation 2004) coordinated by the German Sport Confederation and including national partners on the project team from Sweden, Czech Republic, the UK and The Netherlands; and the European Athlete as Student (Oulu Region Academy of Sport 2004) co-ordinated by the City of Oulu Department of Education together with the Oulu Region Academy of Sports. The main aim for this project was to create a cooperative network between the participating partners (the project began with seven formal partners but eventually encompassed 20 partners in total) in order to improve athletes' opportunities of combining athletic activities and academic demands and to define a European approach to dealing with the education of athletes (Oulu Region Academy of Sport 2004). More recently the European Commission funded a study on The Training of Young Sportsmen and Sportswomen in Europe (INEUM Consulting and TAJ 2007). This was a response to the concerns of the sports movement and Member States in relation to the quality of the training of sportspeople in Europe. The main purpose of the study was to identify ways of improving the legal and political framework for preserving and developing high-quality training for elite sportspersons, and in particular young sportspersons, without compromising other aspects of their lives such as education.

It is against this background that the research project, parts of the findings of which are reported here, was commissioned by the Sports Unit of the European Commission. Its principal aim was to map out policy approaches to education for elite sports persons in the (at that time 25) Member States of the EU.

\section{Methodology: comparing policy systems}

The data subject to analysis in this study were the detailed qualitative descriptions of the policy approaches adopted in each of the 25 Member States provided by research groups recruited for this 
purpose. These were provided by research teams recruited for the study with expertise in the field of education and/or 'performance lifestyle' support services in each of the 25 Member States. Such qualitative accounts were critical to capturing detail in respect of how the system operated and was evaluated. Each qualitative account was the summary of material reported in either two or three stages of data collection.

The first data collection stage involved the completion by each Member State team of a 'template', identifying the nature of educational provision for elite athletes in the particular state for each of five areas of education.2 This template required a detailed description of measures and practices concerning educational provision for elite athletes. The second stage required each team to identify and summarise evaluations of examples of these forms of provision where such evaluations existed. The third data collection stage involved four core teams (France, Germany, Poland and UK) in identifying and evaluating case studies of particular interventions in this domain. These three elements - description of provision of services to athletes in higher education; evaluations of the effectiveness of such provision; and analysis of cases of particular interest - provided a framework against which comparison of the accounts of national systems could take place.3 It is important to note that what was to be subject to analysis here was not the data provided by the experts as such, but the experts' accounts themselves. The analysis was thus conducted on the basis of an identification and evaluation of the themes evident in the detailed policy descriptions provided by each team.

Comparative analysis, and in particular comparative policy analysis, offers particular challenges. We have characterised elsewhere methodological approaches adopted in comparative analysis as falling into four types or categories, each with differing ontological and epistemological characteristics (Henry and Institute of Sport and Leisure Policy 2007, chapter 2). These are: a positivist approach (focusing through statistical analysis on the identification of shared statistical associations between the dependent policy variable and independent variables relating to local social, economic or political conditions); an ideographic approach (seeking to compare descriptions of policy systems and processes which allow us to define differences in the ways in which policy systems operate); a transnational approach (seeking to theorise transnational as well as local/ national influences on policy); and discourse based approaches (which seek through discourse analysis to explain how the policy universe and the possible options are prescribed and proscribed through their discursive construction, largely in political and policy statements).

In the context of this study the lack of comparable statistical data, and the variability in meanings ascribed to statistical data precluded the use of a positivist approach. A discourse analysis based approach was also not appropriate given that the raw data was not the policy statements themselves, but the experts' accounts of the development of policy in this area in each country (provided in English). The approach which was adopted in this study drew on aspects of the two remaining approaches. It was ideographic, dealing with expert descriptions / accounts of national systems, and grouping themes evident in these accounts together in ideal typical frameworks. The approach was also transnational in the sense that it sought to identify and explain phenomena such as policy learning and policy transfer across borders as well as the activities of bodies operating in transnational space, most notably the European Union.

\section{Research findings: policy approaches to the provision of higher education for elite athletes}

Our focus in this paper is on higher education and its adaptation to accommodate the delivery of education to elite athletes. The review of policy descriptions undertaken highlighted three principal categories of policy initiative within the university and higher education sector in respect of elite sportspersons namely the development of academic services, elite sporting provision, and postathletic career preparation or support (see Figure 1). In so far as our concerns are with academic delivery the discussion below relates principally to the first and, to a lesser degree, the third of these categories.

The differing approaches to academic policy in relation to elite athletes derived from the process outlined above allowus to define in ideal typical terms the nature of the different policy positions taken upwithin theMember States. What follows below is therefore an account of the nature of these ideal types and a discussion of the extent to which the policy systems of individual Member States 
conform to, or differ from, these ideal typical frameworks.

The findings of the study underline the variability of response in national systems to the demands placed on elite young sportspersons. The situation across the Member States ranges from negligible provision to established structures backed by legislation. We characterise these responses in a fourfold typology. The first type is state centric provision where action on the part of educational providers is required by legislation or by state regulation. The second relates to those systems in which the state acts as a facilitator fostering formal agreements between educational and sporting bodies or individuals. The third system is one in which the National Federations or Sports Institutes engage directly in negotiation with educational bodies on behalf of the individual athlete. The fourth type is one of 'laisser faire' where there are no formal channels or structures in place and where accommodation of the student-athlete's needs is either not admitted, or is largely a matter of individually and informally negotiated arrangements.

Table 1 summarises these positions, and the typology is outlined more fully below. It is important to acknowledge that the typology is based on an ideal typical account and thus individual nation states may exhibit traits of more than one ideal type, not falling neatly into a single category. This may be particularly true in states in which education policy and / or sports policy are not direct responsibilities of the central state, and thus where there may be greater variation within the system. Nevertheless we argue that the typology serves a useful heuristic role.

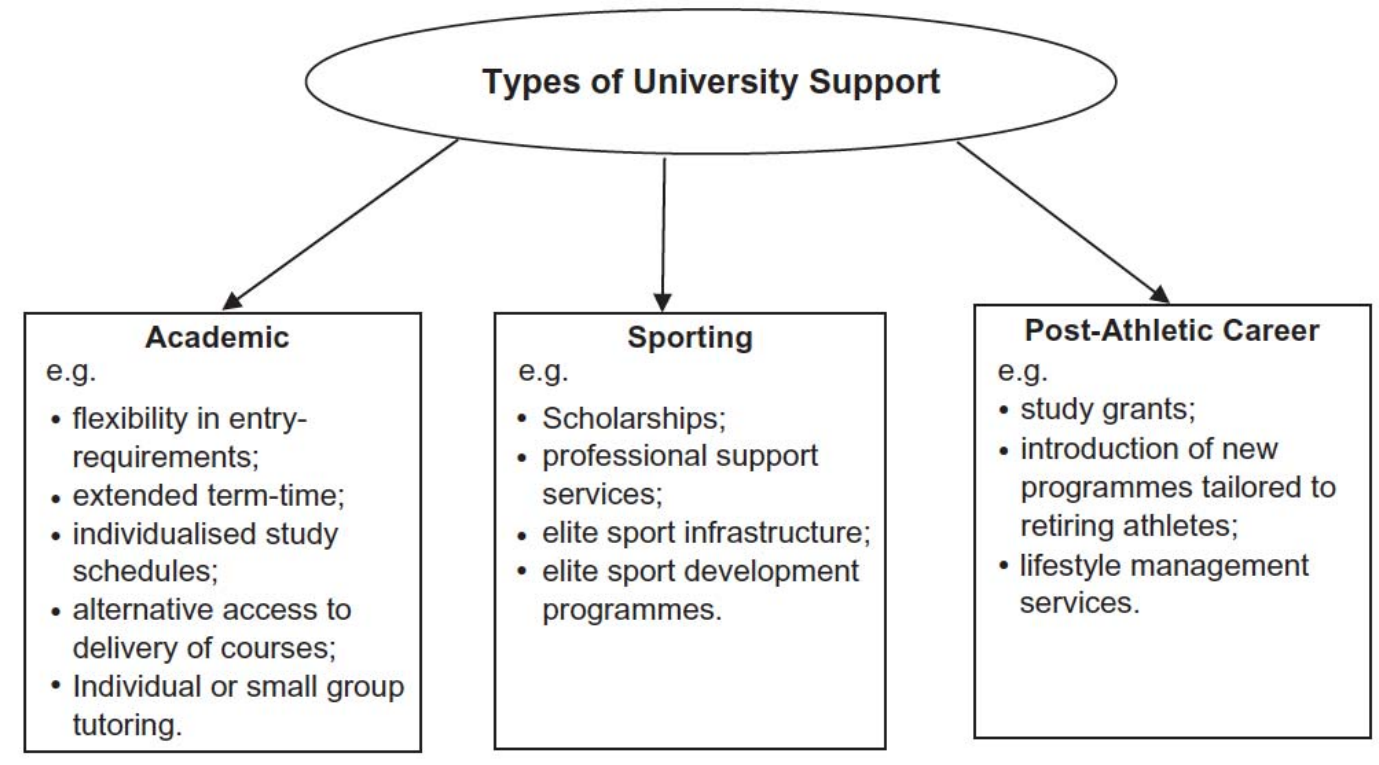

Figure 1. The adaptation by universities of services for elite young sports persons.

\section{State-centric regulation}

This type of policy response is characterised by a requirement, typically via legislation or state regulations, placed on academic institutions to provide adapted opportunities for student-athletes in terms of entry-requirements, time-tabling flexibility, exam dates and type of course delivery. Such arrangements are evident in France, Hungary, Spain and Portugal.

\section{Entry requirements}

There is a range of provisions which fall under this heading from at one end of the spectrum, waiving or reduction of entry requirements for any course, through waiving or reduction of sport related courses, to provision of tailor made courses. Perhaps the most radical of cases is that of Hungary where legislation provides Olympic medallists with the right to be admitted to any college/university 
without an entrance examination (Ministerial Decree on the General Regulations of Admission Procedure at Colleges/Universities 246/2003. [XII.18.]).

Table 1. Typology of approaches to educational services for elite athletes in higher education.

\begin{tabular}{|c|c|c|}
\hline Type & Key Features & Examples \\
\hline $\begin{array}{l}\text { 1. State-centric } \\
\text { Regulation }\end{array}$ & $\begin{array}{l}\text { Responsibility is placed on HE } \\
\text { institutions to provide adapted } \\
\text { opportunities for student-athletes } \\
\text { through legislation, statutory } \\
\text { requirement or government } \\
\text { regulation. }\end{array}$ & $\begin{array}{l}\text { France, Hungary, Luxembourg, } \\
\text { Spain, Poland, Portugal }\end{array}$ \\
\hline $\begin{array}{l}\text { 2. State as Sponsor/ } \\
\text { Facilitator }\end{array}$ & $\begin{array}{l}\text { An approach where by the state } \\
\text { promotes formal agreements to } \\
\text { ensure that student-athletes' needs } \\
\text { are being met at University level, } \\
\text { for example through 'permissive } \\
\text { legislation'. }\end{array}$ & $\begin{array}{l}\text { Belgium (Flanders), Denmark, } \\
\text { Estonia, Finland, Germany, } \\
\text { Latvia, Lithuania, Sweden. }\end{array}$ \\
\hline $\begin{array}{l}\text { 3. National Sporting } \\
\text { Federations/ } \\
\text { Institutes as } \\
\text { Intermediary }\end{array}$ & $\begin{array}{l}\text { There is an established system of } \\
\text { recognised channels for sporting } \\
\text { advocates (usually national } \\
\text { governing bodies or national } \\
\text { institutes of sport) to act on behalf } \\
\text { of the student to negotiate flexible } \\
\text { educational provision with HE } \\
\text { institutions. }\end{array}$ & Greece, United Kingdom \\
\hline $\begin{array}{l}\text { 4. Laisser Faire: no } \\
\text { formal structures }\end{array}$ & $\begin{array}{l}\text { There are no structured measures in } \\
\text { place and arrangements rely on } \\
\text { individually negotiated agreements } \\
\text { where these prove possible. }\end{array}$ & $\begin{array}{c}\text { Austria, Cyprus, Czech Republic, } \\
\text { The Netherlands Ireland, Italy, } \\
\text { Malta, Slovakia, Slovenia }\end{array}$ \\
\hline
\end{tabular}

In accordance with the same ministerial degree, admission procedures (for higher education), advanced standing is provided for elite athletes in the form of bonus points in a points-based competition for admission to courses. Thus five bonus points are given to athletes placed in the top three in world or European championships held in any Olympic sport (but only in Olympic sports) and three bonus points to those in the top three in national championships (again exclusively in Olympic sports).

In Poland elite athletes are not accorded direct entry to higher education by right but candidates who have achieved 'outstanding results' for Polish sport can be granted access to university by the Minister of Education and Sport at the request of the relevant Polish sport association, without the requirement of having to take the matura exam. There is also a system to offer advanced standing at the six Physical Education academies in Poland (plus two external branches) where for example a student-athlete has certain qualifications in the area of physical culture, such as a sports instructor qualification (for each such qualification candidates accrue a bonus point). Although these are requirements for the physical education institutions, some other universities also reward sportspersons with bonus points during the admissions process.

In Spain universities are compelled by law (Royal Decree 1467/1997, 19 September) to reserve 3\% of the total places provided by universities for elite / high performance sportsmen and women accredited as such and who meet general university entry requirements. The centres that teach the Degree in Physical Activity and Sport Studies as well as the National Institutes of Physical Education are compelled by law to reserve an additional number (equivalent to 5\%) of the places provided for high performance sportsmen and women. 
Table 1. Typology of approaches to educational services for elite athletes in higher education.

\begin{tabular}{|c|c|c|}
\hline Type & Key Features & Examples \\
\hline $\begin{array}{l}\text { 1. State-centric } \\
\text { Regulation }\end{array}$ & $\begin{array}{l}\text { Responsibility is placed on HE } \\
\text { institutions to provide adapted } \\
\text { opportunities for student-athletes } \\
\text { through legislation, statutory } \\
\text { requirement or government } \\
\text { regulation. }\end{array}$ & $\begin{array}{l}\text { France, Hungary, Luxembourg, } \\
\text { Spain, Poland, Portugal }\end{array}$ \\
\hline $\begin{array}{l}\text { 2. State as Sponsor/ } \\
\text { Facilitator }\end{array}$ & $\begin{array}{l}\text { An approach where by the state } \\
\text { promotes formal agreements to } \\
\text { ensure that student-athletes' needs } \\
\text { are being met at University level, } \\
\text { for example through 'permissive } \\
\text { legislation'. }\end{array}$ & $\begin{array}{l}\text { Belgium (Flanders), Denmark, } \\
\text { Estonia, Finland, Germany, } \\
\text { Latvia, Lithuania, Sweden. }\end{array}$ \\
\hline $\begin{array}{l}\text { 3. National Sporting } \\
\text { Federations/ } \\
\text { Institutes as } \\
\text { Intermediary }\end{array}$ & $\begin{array}{l}\text { There is an established system of } \\
\text { recognised channels for sporting } \\
\text { advocates (usually national } \\
\text { governing bodies or national } \\
\text { institutes of sport) to act on behalf } \\
\text { of the student to negotiate flexible } \\
\text { educational provision with HE } \\
\text { institutions. }\end{array}$ & Greece, United Kingdom \\
\hline $\begin{array}{l}\text { 4. Laisser Faire: no } \\
\text { formal structures }\end{array}$ & $\begin{array}{l}\text { There are no structured measures in } \\
\text { place and arrangements rely on } \\
\text { individually negotiated agreements } \\
\text { where these prove possible. }\end{array}$ & $\begin{array}{c}\text { Austria, Cyprus, Czech Republic, } \\
\text { The Netherlands Ireland, Italy, } \\
\text { Malta, Slovakia, Slovenia }\end{array}$ \\
\hline
\end{tabular}

The same Royal Decree also established permissive legislation to allow the Sports Council to sign agreements with the Autonomous Communities, and with non-state universities and private educational institutions so that high performance athletes can enjoy special conditions relative to their access to, and programmes in, these institutions on condition that they meet the general academic requirements which are necessary for entry.

However, although legislation providing a statutory requirement to support access to higher education may be in place, implementation may be weak as in the case of Portugal (Lei de Bases do Desporto 1995), (Amara et al. 2004: Appendix C).

In France, the situation with regard to entry requirements is somewhat more complex. Provisions concerning the admission of high-level athletes to institutions of HE are outlined in Circular No. 1455 of October 1987. However, since the management of universities is decentralised, the circular invites university deans, school directors and regional directors of education to undertake the necessary measures to accommodate high-level athletes who wish to combine sport activities and studies. Each year the Ministry of Health awards exemption to 20 elite athletes from entrance exams to the first year of courses at Institutes for Physiotherapy and Chiropody.

\section{Type and location of education provision}

However, the French state also operates five state-run national sports institutes to accommodate elite athletes, namely: the National Institute of Sport and Physical Education (INSEP); the National School of Ski and Mountaineering (ENSA); the National School of Sailing (ENV); the National Equestrian School (ENE); and the National School of Cross- Country Skiing and Ski Jumping (ENSF). At the largest of these, INSEP, there are opportunities to combine high level sport with a whole range of academic programmes, from compulsory schooling to higher education diplomas and university degrees. It is estimated that about $50 \%$ of former pupil athletes stay at INSEP to pursue postsecondary education. INSEP offers different options to pursue college-level or university-level sportsrelated studies (e.g. diploma in coaching, sports and PE studies, sports administration, sports management). Rather than necessarily providing access to existing university courses, in the INSEP system, teaching staff come to the sports establishment to teach the studentathletes depending on 
their level and subjects of choice, though a number of student-athletes living in INSEP also attend universities in the Paris region (Coalter and Radtke 2007).

\section{Examination and time-tabling flexibility}

Each of the above countries also has legislation or state regulation in place to permit flexible arrangements for examination and timetabling or course length to be offered to elite sportsmen and women. These include, in the case of France for example, the postponing of examinations which impinge on competition or training schedules or the staging of examinations or other forms of assessment in venues such as training camps.

\section{State as sponsor/facilitator}

The second category of policy response within this typology is characterised by a formal system for acknowledging student-athletes' needs, but which stops short of a legal requirement. Thus in this second category of policy response government plays a significant but less directly interventionist role, enabling rather than regulating university responses to the specific needs of the student-athlete, often on the basis of permissive legislation rather than statutory requirement. Seven national systems fall within this category, namely Belgium (Flanders), Denmark, Estonia, Finland, Germany, Latvia, Lithuania and Sweden.

\section{Facilitating entry requirements}

Within this type of approach there have been a number of initiatives that were developed by some universities (rather than states per se) to facilitate the entry requirements for studentathletes. For example at the University of Copenhagen in Denmark, the Institut for Idræt (Institute of Exercise and Sport Sciences) decided in $\mathbf{2 0 0 0}$ that experience gained from involvement in elite sport would be accepted as a relevant qualification in applications for admission through kvote 2 . In kvote 2 a small number of study places (usually about $10 \%$ of the total number) are given to students achieving entry grades from final high school level examinations (the studentereksamen) with an average grade that is not high enough for direct admission to the faculty. In kvote2 students can add to their qualifications by proving that they have been involved in activities relevant to the content of the field of study which they want to enter, and in the case of applicants to the Institute of Exercise and Sports Sciences, elite sport is considered a relevant activity.

On a larger scale similar initiatives were developed in Germany through a co-operation agreement that was established initially with 45 Universities (encompassing over 800 national squad athletes) between the major governing education and sporting bodies responsible for elite athletes. These universities offer reduced entry criteria for athletes and special efforts are made to promote athletes within the university system (German Sport Confederation 2004).

Concessions for elite athletes who want to further their academic career in Latvia are decided by the particular HE institution they wish to attend, and some institutions have moderated entry requirements. The Latvian Academy of Sport Education admits without the need to sit entrance exams members of the national Olympic and Paralympic teams, athletes placed in the top twelve for the World and European championships, or the World and European junior championships, in Olympic sports, and graduates of Murjani Sport Gymnasium and Riga Secondary School Nr.90. The Lithuanian Academy of Physical Education offers advanced standing (in the form of extra points in the admissions process) to talented sportspersons if they are placed in the top three in the Olympic,World or European, Senior, Youth or Junior Championships, or if they achieve a top three placing in the Lithuanian Senior Championships, they are junior champions, or they possess a Lithuanian Physical Education qualification.

\section{Delivery of courses}

As a result of the significant amount of time that student-athletes have to spend away from their university on training camps or competitions abroad, some universities are providing alternative access to the delivery of courses through initiatives such as e-learning or distance learning in an attempt to compensate for missed lectures. There are a number of academic institutions which offer this service in European countries such as Denmark, Sweden and Estonia. 
Since 2000, in Denmark the Ministry of Education has, according to Team Danmark and the Ministry of Science, Technology and Innovation, established some measures necessary for elite sports people at HE institutions. Student-athletes in Denmark can benefit from distance learning initiatives developed by their institutions while Team Danmark further supports its athletes by providing laptops for student-athletes so they can access materials while they are away.

In the case of Estonia two universities offer specialist education to elite athletes - the University of Tartu and Tallinn Pedagogical University. Student-athletes are allowed extensions of time to complete their courses and follow an individual curriculum. Some universities also support top athletes by allowing them to extend their period and timing of study, and in addition, many offer courses by distance-learning.

The Swedish Olympic Committee manages a support programme for elite athletes who wish to combine a sporting and an academic career in higher education. University degrees / courses are partly organised as distance learning education where the student-athlete has the responsibility to manage their own programme of study. Specially designed programmes across a number of universities are also available in order to fit the athletes' schedule.

\section{Scholarship awards/contracts}

In Belgium the opportunity to combine elite sport and studies professionally has beenfacilitated since 2003 through an agreement, the 'Topsportconvenant HO', between the Ministry of Sport, Flemish Sport Governing body (Bloso), Belgian Olympic Interfederal Committee and Sport federations, where two universities and three polytechnics took on a range of responsibilities with regard to elite athletes. Through this formal agreement, Belgian Olympic student-athletes are eligible for a contract to the value of $70 \%$ of a full time professional Olympic athlete. Awards are made to student-athletes on Olympic lists specifically to allow them to combine elite sport and studies in higher education. This contract is an inclusive package comprising professional coaching, training at top facilities, professional support services and enhanced academic opportunities. Incorporated in this arrangement is a scholarship of $€ 20,000$ enabling student-athletes to pay for specific elements related to the combination of elite sport and study (e.g. registration fees) as well as specific support for sport (e.g. a sport psychologist). A second initiative established as part of the law began during 2004/2005 academic year. This included young Olympic athletes (i. e. those selected for the Belgian Youth Olympic team) who register at a university or at an academic institution of HE outside of university. While they will not receive a contract, they will receive financial support allowing them to combine HE and elite sport.

In Denmark a two-year strategy 'Contract of Results' (2006-2008) was agreed between the Ministry of Culture and Team Danmark which reinforced once more the holistic development of the athletes through the creation of educational and job opportunities. Elite athletes affiliated to Team Danmark must comply with their job and education policy which requires them to either have a job or be enrolled in an education programme alongside their sporting career. Athletes that do not meet this requirement are contacted by a study director to make a career plan and if they are not willing to adhere to this policy run the risk of being taken off the National team programme (Falkentoft 2007).

The Finnish Ministry of Education Awards grants for athletes proposed by the Olympic Committee and the Paralympic Committee who on the basis of their international performance have potential for winning a medal in the Olympic or Paralympic Games, or in the World Championships. The level of the tax-free sport grant is either $€ 6000$ or $€ 12,000$ per year. Grants are allocated in both summer and winter Olympic sports as well as in non- Olympic and Paralympic sports. The total amount of sports grants for the year 2004 was $€ 558,000$ (Merikoski-Silius 2006). The criterion for allocation of a full $(€ 12,000)$ Athlete's Grant is that the athlete has reached 6-8th place in the individual competition of the season's main event (Olympic Games, World Championships or World Cup overall competition). The criterion for the grant of $€ 6000$ is that the athlete has finished 8-12th place in individual competition for these same events. The criterion for the award of a young athlete's grant is that the athlete attain $12-15$ th place in the corresponding competitions. An athlete who is awarded a grant must sign a training contract with the given Sports Federation and the Finnish Olympic Committee, in which the athlete agrees to follow the existing anti-doping rules as well as other requirements such as having a personal study programme (Kanerva 2004). 
Other types of individual support and financial assistance are also available in other member states, for example in Denmark educational institutions can apply to Team Danmark for financing supplementary teaching for sportspersons and to finance additional study benefits, while in Estonia support is available in the form of government scholarships and awards. National Sporting Federations/Institutes as intermediaries

The third type of policy approach is one in which the athletic development needs of the individual are catered for by the sporting institutions (national governing bodies of the particular sport or national sports institutes) and where staff of these sporting entities may advise and act on behalf of the student-athlete to secure 'appropriate' educational arrangements. The UK and Greece provide contrasting examples of this approach.

\section{Formal lifestyle performance support services}

The UK, through its various National Institutes of Sport, has established regional hubs where athletes can access a variety of services from medical help to lifestyle counselling. Lifestyle performance advisers are available to help student-athletes plan their time-tables months in advance to avoid any clash of commitments between sporting and educational obligations. Performance Lifestyle Advisors will also negotiate directly on behalf of student-athletes if unforeseen problems arise, an approach which is often facilitated by the fact many such advisors are based on university campuses. While the state substantially funds the elite sporting and higher education systems management of the relationship between the two is left to these third parties. The UK system results in local variations in terms of practice on admissions, rescheduling of examination and assignment dates, extensions to the length of time students may be registered and the availability of dedicated academic tutoring support. Thus, although the system for elite athletes at least is widespread (though not universal) the outcomes achieved do depend on the effectiveness of the relationship established between Performance Lifestyle Advisors and the athlete-student on the one hand and with the university staff on the other.

\section{Informal lifestyle/career support services}

While in the UK, there is a relatively structured approach, by contrast in Greece there is an on-going struggle to ensure such services for student-athletes. Sport federations are fully aware of studentathletes' needs and are prepared to support the members of their national teams by for example providing the necessary documentary evidence to Academic Institutions when athletes ask for special arrangements to be made because of sporting commitments. However, since there are no equivalents to the role of the Performance Lifestyle Advisor, in many instances the athlete is simply dependent on the public relations skills of the staff of their sporting federation, and on the good will of academic staff. In such a situation athletes are subject to inequitable treatment, by universities and/or by their sport organisations. Indeed, gaining flexibility in study arrangements with 'special treatment', especially outside of sports science departments, is a matter of personal negotiation can prove to be very difficult.

\section{Laisser faire: no formal structures}

While the third category of response outlined above is one in which sporting authorities provide designated individuals to support athletes in negotiating with educational bodies, the fourth approach relates to cases in which there are no formal structures and any arrangements (where these prove possible) largely rely on individually negotiated agreements. Thus, what are evident in the national systems grouped in this category is not shared policy themes, and the countries are therefore identified here in terms of the rationale for their failure to provide student-athlete services in a formal manner. This category includes four sub-groups: small states (e.g. Malta and Cyprus); conservative national education systems (e.g. Italy and Ireland); a state with open access to higher education (Austria); and a state with some permissive measures but which legitimates only ad hoc individual responses (Netherlands).

\section{Small states}

There are two small states in this category (Malta and Cyprus) in which the national higher education systems are relatively small such that adaptation to athletes' needs may be seen as unduly disruptive. The case of Cyprus is somewhat unusual in that while provision for student athletes is not made 
within the country, for those who wish to study in Greece special arrangements are made. The Ministry of Education and Culture within the framework of its policy for the development of sports, has developed an incentive scheme for young sportspersons by granting them 'bonus points' if they wish to continue their studies in the Universities of Greece, in the Department of PE and Sports Science. Hence, this opportunity is restricted to a specific educational category and if the athlete chooses to follow subjects outside the sports domain, s/he will gain no benefit from this scheme. However, it is important to note that $80 \%$ of Cypriot athletes following a post-school education, study and train abroad with foreign coaches, most of them in Greece.

\section{Conservative education systems}

The cases of Italy and Ireland reflect the conservative educational outlook of traditional universities in each of the countries. In Italy, where state centrality in sporting governance has been the norm, the situation is still problematic in terms of securing flexibility for athletes. This has been exacerbated by relatively recent changes in the institutional location of, and responsibility for, sport related degrees such as those in Physical Education and Sport Science. In the Italian university system prior to 1999, there were 15 Institutes of Physical Education, but currently there are about 30 universities offering sport related courses. However many courses are provided within faculties of Medicine. Some of the universities have ad hoc links with sport federations but these tend not to be strong or consistent, and it is not uncommon, for example when examinations and international sporting commitments clash, for faculties to refuse to make exceptions. There is, however, some financial support from a number of sport federations which provide bursaries to student-athletes to further their education at universities.

In Ireland, elite student-athletes who are combining formal education and a sporting career generally find that the higher education system is rather restrictive. There is little flexibility afforded to elite sports participants with respect to the completion of courses or programme elements. However, some concessions do exist, for example in the Waterford Institute of Technology there are places reserved for individuals who are competent in particular sports and are guaranteed places on a third level Recreation and Leisure Course. These places are usually offered on the basis of one per sport such as cycling, equestrian, swimming, athletics etc. These students may not meet the points (CAO) requirements for this course, but they must meet the minimum entry requirements of the college and they are guaranteed a place on the course, but receive no financial assistance. At University College Dublin (UCD) talented athletes are advised to register for the Diploma in Sports Management should they fail to meet academic entry requirements for other programmes. The diploma in sports management is a two-year part time programme that aims to provide a foundation in the necessary skills for a sports related career.

\section{A state with open access to education}

The Austrian university system does not provide quotas for the admission of athletes or propose any official provisions for the flexibility of athletes studying at university. The main reason for this being that there is open access to third level education in Austria, however some university professors have been prepared to discuss special arrangements with athletes on an individual basis.

\section{A state with permissive measures allowing ad hoc responses}

In the Netherlands, despite the existence of study grants for students generally, special provisions or arrangements for elite athletes are not institutionalised. There is a study guarantee fund from the National Olympic Committee / National Sports Federations (NOC*NSF) for 'A-status' and 'B-status' elite athletes who do not have a stipend. In the Netherlands, each student is entitled to receive a study grant for four years. However, because of sporting commitments, elite athletes often require more time to complete their studies. A-status elite athletes may receive a maximum grant of $€ 3267$ for four extra years and B-status elite athletes a maximum of $€ 1633$ for two extra years. This assistance is thus sourced outside of the education system, and negotiation with educational institutions is still largely a matter of ad hoc 'bargaining' at the individual level.

What we have sought to provide so far is a rich description and categorisation of policy systems, whereas in this concluding section we seek to explain why such policy patterns emerge in particular 
nation-states.

\title{
Conclusions
}

\section{Explaining the emergent policy pattern}

What then can be concluded from the pattern of provision evident in the above survey of practices? There are perhaps three critical features which are important to stress here. The first is the variability in state intervention from a strong 'hands on' approach to virtual 'laisser faire'. Four discernable factors underlie this pattern. The first is local political culture and history. If we take the example of France, the tradition of the dirigiste state is one which has seen state intervention in a broad range of social and cultural fields which would be International Journal of Sport Policy 39 anathema to more liberal states. In addition Hungary's radical approach to, for example, allowing open access or advanced standing of athletes to higher education represents a residual element of the political culture of the communist era. The second factor explaining this variability is that of local academic culture. In the Italian case, for example, the location of sports science in medical faculties has meant that the sports domain has been subject to the relatively unyielding standards of professional education in medicine, which allows for relatively little variation in the application of access, progress and examination regulations. The third factor which is evident is that of size and the availability of economies of scale. Small states such as Cyprus and Malta have relatively small higher education systems and resourcing special provision for athletes or any other special group may place an undue burden on the small resource base. The fourth factor is the importance of individual agency and advocacy in certain systems where policy entrepreneurs (Laffan 1997, Mackenzie 2004) were significant influences in the adoption of special measures for athletes. (Professor lan Thompson at the University of Stirling in Scotland and Professor Paul De Knop in the Vrije Universiteit Brussel in Belgium provide good examples of the influence of such individuals.)

The second point to highlight is the apparent and growing willingness for greater intervention in this area. This may be motivated as much by concerns with enhancing athletic performance by removing 'worries' about dealing with the demands of education, as with a concern for the rights of athletes, but nevertheless it is evident as part of a growing concern in elite sports policy (Green and Houlihan 2005).

The third point to emphasise is that the variability in policy response in this area effectively means variation in citizens' rights and athletes' rights, and this has implications for the European Union in terms of interventions that can address such inequalities. The European Commission has shown increasing interest in the protection of athletes' rights in recent years and, for example, in publishing the findings of its most recently commissioned study in this area (INEUM Consulting and TAJ 2007) it has declared that:

\begin{abstract}
Although they do not constitute the Commission's official position, the Commission considers these results as useful input for the cooperation it intends to pursue with governmental and nongovernmental stakeholders to promote the quality of sports training in the EU and to protect the moral and physical integrity of young sportspeople in the European Union. (European Commission 2008a)
\end{abstract}

\section{Roles, rights and responsibilities of key stakeholders}

Clearly an element in the quality of the system of education of elite athletes is the extent to which athletes' rights (particularly, but not exclusively, those of minors) are recognised and protected. If the State is fostering participation in elite sport development while making no attempt to modify the educational provision, then the athletes' rights to education will de facto be affected.

Crucial to an evaluation of the systems summarised in the typology outlined in this paper is an understanding of what these policy systems are seeking to achieve. This may be expressed in terms of a balance between the obligations and the rights of the various stakeholders: the athlete; the university; the nation-state; and the European Union. Where rights are acknowledged to exist, for example, the State can 'expect' of the athlete a sustained attempt to fulfil athletic potential on the basis of support from the public purse, while the athlete can 'expect' from the State equity/comparable treatment in terms of the educational experience delivered. Equity in this context is probably best conceptualised as equity of throughput (rather than resource input or output/performance). Equity of throughput implies access to equivalent amounts of tutor support, 
time for preparation of assignments and examinations and the freedom to undertake examinations without undue pressure of international sporting performance.

Table 2 summarises the roles, rights and responsibilities of the primary stakeholders in the system. In an ideal world these three 'Rs' would perhaps constitute the basis of the design and implementation of an elite sports policy system which flows from the discussion of the typology above.

Table 2. A summary of roles, rights and responsibilities of the main stakeholders in higher education and Professional Academies for elite athletes.

\section{The athlete}

Roles: Citizen; Athletic representative of the state

Rights: access to education; support from state and from the university (where there is an implicit or explicit 'contract') in meeting demands of sport / education

Responsibilities: to the university and the state.

\section{The university}

Roles: provision of educational, sporting and lifestyle management services

Rights: responsible representation by athlete

Responsibilities: to maintain the quality of provision while enhancing athlete well being.

\section{The Professional Academy}

Roles: Developer of sporting skills on behalf of (a) club, (b) the National Sports Federation;

Rights: Return on investment in terms of access to player services.

Responsibilities: to commercial stakeholders to provide return on investment; to ensure that commercial exploitation does not impinge on players' rights

\section{The Member State}

Roles: Guarantor of social rights; allocator/regulator of educational and sporting resources

Rights: to be represented responsibly by athletes supported

Responsibilities: equality of treatment of citizens; where additional demands placed on citizens, additional resources provided.

\section{The European Union}

Roles: Enhancing the knowledge base of Member States and highlighting inequities; protection of the individual's rights against the Member State (ECJ);

Rights: for Member states to conform to appropriate legislation; to negotiate with Member States where shared competence exists

Responsibilities: subsidiarity principle applies, responsible (either alone or jointly with Member States) for resource allocation or regulation

\section{Nation-states, welfare regimes, and education for elite young sportspersons}

What this paper has outlined so far might be said to constitute meso-level analysis, insofar as the categories and description of policy actions, and their implications for identifying rights and responsibilities have been delineated. However, analysis at the macro-level of the role of the state, and inter-governmental levels are discussed in the following sections of the paper. Bergsgard et al. (2007, p. 4) and Houlihan and Green (2008) have debated to some degree the extent to which sport policy is said to be shaped in a way that 'reflects the broader welfare regime' of a particular nation. These observations were based on the analysis of welfare states put forward by Esping-Andersen (1990) who identified three types of welfare regimes: liberal, conservative and social democratic. The hypothesis driving this analysis indicates that the socio-economic and cultural foundations of a country collectively referred to as 'welfare regime' influence the way policy is shaped.

In his typology of welfare states 'types' as illustrated in Table 3 below, the first classification by Esping-Andersen included liberal states. Suchwelfare regimeswhich include countries such as the UK, the USA, Canada and Australia are characterised by the central role that the market plays with as little intervention from the state as possible. Some of the basic principles underpinning liberal states are freedom of thought, the rule of law, individual's rights and a transparent systemof government. The general premise is that economic systems based on free markets are more efficient and generate 
more wealth for the country. Rose (1992, p. 142) has argued that under advanced liberalism the state has a limited role to 'provide for and answer society's needs, and individuals, organisations, companies, sport organisations must take increasing responsibility for their own well-being and welfare' (cited in Green 2004, p. 378). As Green further argues under such conditions the notion of the 'active responsible self' is reinforced and therefore individuals are increasingly being expected to take responsibility to fulfil their needs. In the context of this research this argument can be extended to the student-athletes living in such countries who may be expected to assume full responsibility in relation to their educational and sporting career development.

The second type of classification by Esping-Andersen was a conservative corporatist regime, an approach typical of much of continental Europe, including countries such as Belgium, Germany and Italy. This type of regime is driven by the central role of the family (familialism) and the subsidiary role of the state. The emphasis is strongly on 'compulsory social insurance' which suggests that private market provision of welfare remains marginal.

Houlihan and Green (2008, p. 18) point out that social security systems in this type of approach are based on occupational schemes and corporatist status divisions which privileges the treatment of public civil service. In relation to elite athletes there are a number of ways in which the French government as an example continues to demonstrate its commitment towards providing social insurance cover. Bayle, Durand and Nikonoff (2008, p. 153, cited in Houlihan and Green 2008) have noted how the French state has created a number of contracts to ensure that elite athletes gain access to the labour market. Such contracts which are signed by the athlete, his/her sport federation and the employer are intended to facilitate the demands of a dual career while the athlete is still actively engaged in elite sport and to then provide an opportunity for a post-athletic career following retirement fromsport. 'In 2007, 643 elite athletes took advantage of this type of contract which benefited their employer to the tune of $€ 1,389$ of state aid. In $70 \%$ of the cases, the employer is a state (national level) or local authority' (Bayle et al. 2008). In addition the government is also in a process of discussion over plans to offer salaried athletes access to various public pension saving schemes and benefits.

The third regime type - social democratic corporatist, encompasses mostly the Nordic countries. This type is characterised by the central role that the state plays in financing and organising the welfare benefits available to the public such as free education, healthcare, and childcare. Such welfare benefits are compensated for by a high taxation system resulting in income distribution. Due to the high state intervention in all public matters in such societies there is only a limited role for the individual.

\begin{tabular}{|c|c|c|c|}
\hline Type of Approach & $\begin{array}{l}\text { Welfare state } \\
\text { 'regime type' }\end{array}$ & Examples of countries & Characteristics of 'welfare regime' \\
\hline State Centric Regulation & $\begin{array}{r}\text { Conservative } \\
\text { corporatist }\end{array}$ & $\begin{array}{l}\text { Continental Europe including Austria, } \\
\text { Belgium, France, Germany, Italy and } \\
\text { the Netherlands }\end{array}$ & $\begin{array}{l}\text { Central role of family (familiarism) and subsidiary role } \\
\text { of state; privileged treatment of public civil service with } \\
\text { social security systems; marginalised private market } \\
\text { provision of welfare }\end{array}$ \\
\hline State as Sponsor/Facilitator & $\begin{array}{l}\text { Social Democratic } \\
\text { Corporatist }\end{array}$ & Nordic countries & $\begin{array}{l}\text { Central role of state; egalitarianism, de-commodified } \\
\text { welfare, minimising or abolishing market dependency; } \\
\text { generous benefit levels, comprehensive socialisation of } \\
\text { risks }\end{array}$ \\
\hline $\begin{array}{l}\text { National Sporting Federations/ } \\
\text { Institutes as Intermediary }\end{array}$ & Liberal & $\begin{array}{l}\text { USA, Canada, Australia, UK, } \\
\text { New Zealand }\end{array}$ & $\begin{array}{l}\text { Central role of market: minimise state, individualise risks, } \\
\text { promote market solutions; prioritise unregulated labour } \\
\text { markets }\end{array}$ \\
\hline
\end{tabular}

Esping-Andersen's account, while referring to the welfare states and welfare rights in the 1980s, nevertheless provides a description of the role of the state in social policy which is complementary to the description of the approaches to the promotion of athletes' rights to education in the 2000s. The relationship between general welfare regime and policy in this specific domain is clearly evident for countries, such as the UK, France and Finland. However, not all are consistent. In Italy for example where state-centric regulation of the order which characterises conservative corporatist welfare states has been traditionally evident in sports policy. CONI (the Italian Olympic Committee) has established a strong corporatist control over sport since the war, though this has recently been 
undermined by the introduction of a commercialised approach to the marketing of CONI services. In relation to education and the rights of young sportspersons, the laisser faire approach evident in Italy is the product of a clash between a strongly conservative approach to education (which implies the freedom from state 'interference' for universities) and a corporatist tendency which has heightened the propensity of the state to intervene in and through sport. In this instance it would seem that a weak sports lobby has lost out to a strong conservative university lobby.

The discussion above has highlighted the various policies adopted by the individual nation states in Europe to facilitate the dual career path of their student-athletes. Furthermore, some insight into how elite sport and higher education policies are affected by the characteristics of the national political system, the welfare regime type and to an extent the impact of the European Union has also been provided.

However, one needs to take into consideration that there may also be potential wider global forces such as the International Olympic Committee (IOC), the World Anti-Doping Agency (WADA) and international sporting federations such as FIFA (Fédération Internationale de Football Association) which are all influencing the way that policies in this particular research area are shaped.

\section{Implications for the role of the European Union}

As we have noted the European Union has demonstrated a significant concern for the protection of athletes in relation to education and training and their integration into the workforce in a post athletic career. This is explicit for example in a number of statements in documents such as the sporting annex to the Nice Treaty, and to the conclusions of the French Presidency delivered in Nice in 2000, and in the recent White Paper on Sport. Promotion of equity or at least good practice thus remains a key concern.

However the potential role for the EU in addressing this policy problem in sport might seem at first sight to be limited. Even if a competence in sport were to be attained, the Lisbon Treaty provisions allow only for a supporting competence. Radical action such as harmonisation of policy in areas governed by supporting competences is explicitly precluded. Nevertheless despite the limitations on practical action one of the responsibilities of the $\mathrm{EU}$ is to highlight unequal treatment of individuals (in this case young elite sportspersons) in different national contexts, particularly where such practices will, for example, promote social exclusion. The commissioning of the research reported here, and other related projects, and the dissemination of their findings reflects this concern. The EU can thus be an important vehicle for keeping this issue on the policy agenda.

However, this problem is as much a problem of education policy as it is of sports policy. If we consider the area of education, which is itself a matter of a supporting competence, the EU has demonstrated that it can foster good practice. The Education and Culture DG describes its role in the following terms:

While each Member State is in charge of its own education and training system, coordinated action can help achieve common aims. The European Commission focuses on two aspects: firstly, co-operation with national authorities and European stakeholders on improving policies and exchanging good practice, and secondly the development and administration of funding programmes. (European Commission 2008a, p. 1)

\section{Notes}

1. The research team study commissioned by the Sports Unit of the European Commission was directed by the second named author and with the first named author as co-investigator. The research team incorporated 25 sub-teams in each of the then 25 Member States recruited by the authors representing national experts. The authors gratefully acknowledge the contribution of colleagues in each of the Member States and in particular Denis Musso and Claude Legrand of INSEP (I'Institut national du Sport et de l'Education Physique), Paris; Karen Petry and Michael Gross of the German Sport University, Cologne; and Jolanta Zysko of the Josef Pilsudski Academy of Physical Education, Warsaw in the three other core counties (France, Germany, Poland together with the UK) 
in this study.

2. Data were sought for five areas as follows: compulsory education; post-compulsory further education; the educational activities of professional and semi-professional academies; university and higher education provision; post-athletic career training and vocational support and lifestyle management. The focus of this paper is however restricted to that on higher education provision for elite athletes.

3. For information on the data collection template employed and a summary of data produced by this process see Appendix C in Amara et al. 


\section{References}

Amara, M., Aquilina, D., Coalter, F., Green, M., Henry, I., and Taylor, J., 2004. Sport and refugees and asylum seekers. Final report. Brussels: European Commission: DG Education and Culture.

Amara, M., Aquilina, D., Henry, I., and PMP, 2004. Education of young sportspersons (lot 1). Final report. Brussels: European Commission: DG Education and Culture.

Andrews, J., 1999. From School sport to sporting excellence: respecting the rights of minors. Physical education, 1 (6), 59-69.

Bayle, E., Durand, C., and Nikonoff, L., 2008. France. In: B. Houlihan and M. Green eds. Comparative elite sport development: systems, structures and public policy. Oxford: Elsevier.

Bergsgard, N., Houlihan, B., Mangset, P., Nodland, S. and Rommetvedt, H., 2007. Sport policy: a comparative analysis of stability and change. London: Elsevier.

Brackenridge, C., 2004. Women and children first? Child abuse and child protection in sport. Sport in society, 7 (3), 322-337.

Coalter, F. and Radtke, S., 2007. Elite sports schools: an international review. Report to the Scottish Institute of Sport Foundation, Department of Sports Studies, University of Stirling.

Conzelmann, A. and Nagel, S., 2003. Professional careers of the German Olympic athletes. International review for the sociology of sport, 38 (3), 259-280.

David, P., 1999. Children's rights in sports: young athletes and competitive sports: exploit and exploitation. The international journal of children's rights, 7 (1), 53-81.

David, P., 2005. Human rights in youth sport: a critical review of children's rights in competitive sports. London: Routledge.

De Knop, P.,Wylleman, P.,Van Hoecke, J.,DeMartalaer,K. and Bollaert, L., 1999.AEuropean approach to the management of the combination of academics and elite-level sport. Perspectives: the interdisciplinary series of physical education and sport science: school sports and competition, 1 (1), 49-62.

Donnelly, P. and Petherick. L., 2004. Workers' playtime?: Child labour at the extremes of the sporting spectrum. Sport in society, 7 (3), 301-321.

Esping-Andersen, G., 1990. The three worlds of welfare capitalism. Cambridge: Polity Press.

European Commission, 2004. European year of education through sport 2004. Brussels, European Commission. Available from: http://europa.eu/scadplus/leg/en/lvb//35008.html [Accessed 10 June 2008].

European Commission, 2007a. Commission staff document: action plan "Pierre de Coubertin", accompanying document to the white paper on sport: com(2007) 391 final; Brussels, European Commission. Available from: http://ec.europa.eu/sport/white-paper/index-en.htm [Accessed 10 June 2008].

European Commission, 2007b. Treaty of Lisbon amending the treaty on European Union and the treaty establishing the European Community. Brussels: European Commission. Available from: http:// www.consilium.europa.eu/uedocs/cmsUpload/cg00014.en07.pdf [Accessed 10 June 2008].

European Commission, 2007c. White paper on sport: COM (2007) 391 final, Brussels, European Commission.

European Commission, 2008a. Education and training. european commission, dg education and culture. Available from: http://ec.europa.eu/education/at-a-glance/about141_en.htm [Accessed 20 August 2008].

European Commission, 2008b. News: study on the training of young sportsmen and sportswomen in Europe. Brussels: Sports Unit - European Commission. Available from:http://ec.europa.eu/sport/ news/news492_en.htm [Accessed 10 June 2008]. 
European Council of Ministers, 2000. Annex IV to the conclusions of the French Presidency of the EU. Brussels: European Commission. Available from: http://ec.europa.eu/employment social/gender equality/docs/2000/euro_council_nice_en.pdf [Accessed 15 August 2004].

European Parliament, 2003. Combining sport and education: support for athletes in the EU member states. Education and culture series, EDUC 114EN. Luxembourg: European Parliament.

Falkentoft, C., 2007. Dual career - in Denmark. Paper delivered at Dual career - balancing top-level sport, education and occupational career conference. 5-6 May, Stuttgart, Germany.

German Sport Confederation, 2004. Education in elite sport in Europe: Final report. Brussels: European Commission: DG Education and Culture.

Giulianotti, R., 2004. Human rights, globalization and sentimental education: the case of sport. Sport in

society, 7 (3), 355-369.

Green, M., 2004. Power, policy and political priorities: elite sport development in Canada and the United Kingdom. Sociology of sport journal, 21 (4), 376-396.

Green, M. J. and Houlihan, B.M.J., 2005. Elite sport development: policy learning and political priorities. London: Routledge.

Henry, I., 2007. Sport, the European Union and the decline of the nation state? In: B. Houlihan, ed. Sport and society. 2nd ed. London: Sage.

Henry, I. and Institute of Sport and Leisure Policy, 2007. Transnational and comparative research in sport: globalisation, governance and sport policy. London: Routledge.

Henry, I. and Matthews, N., 1998. Sport policy and the European Union: the Post-Maastricht Agenda. Managing leisure: an international journal, 3 (1), 1-17.

Henry, I. and Matthews, N., 2001. Sport, leisure and European Union regional policy: a case study of Merseyside UK. In: C. Gratton and I. Henry, eds. Sport in the city. London: Routledge, 330-344.

Houlihan., B. and Green, M., 2008. Comparative elite sport development: Systems, structures and public policy. Oxford: Elsevier.

INEUM Consulting and TAJ., 2007. Study on the training of young sportsmen and sportswomen in Europe. Brussels: European Commission. Available from: http://ec.europa.eu/sport/pdf/ doc497_en.pdf [Accessed 10 June 2008].

Kanerva, J., 2004. The Finnish university system and support for athletes. Paper presented at Elite sportspersons, education and vocational preparation conference. 26 May, UK Sport, London.

Laffan, B., 1997. From policy entrepreneur to policy manager: the challenge facing the European Commission. Journal of European public policy, 4 (3), 422-438.

Lei de Bases do Desporto, 1995. Decreto-Lei no. 125/95 de 31 de Maio. Lisbon: Assembleia da Republica de Portugual.

Mackenzie, C., 2004. Policy entrepreneurship in Australia: a conceptual review and application. Australian journal of political science, 39 (4), 367-386.

Merikoski-Silius, T., 2006. Critical evaluation of aspects of the athletes' study and career support service in Finland. Unpublished Executive Masters in Sports Organisation Management (MEMOS) thesis, Universite Lyon 1, Lyon.

Nier, O., 2004. The development of academies for young professional rugby players in France. In: M. Amara, D. Aquilina, I. Henry and PMP consultants, eds. Elite sportspersons, education and vocational preparation conference. 26 May, London, UK Sport.

Oulu Region Academy of Sport, 2004. European athlete as student project: Final report. Brussels:

European Commission, DG Education and Culture.

Parrish, R., 2003. Sports law and policy in the European Union. Manchester: Manchester University 


\section{Press.}

Skari, T., 2003. A run for the money. Available from: http://www.time.com/time/magazine/article/ 0,9171,901030908-480231,00.html [Accessed 21 August 2003]. 